\title{
REMOVAL OF NITRATE AND PHOSPHATE FROM MUNICIPAL WASTEWATER SLUDGE BY CHLORELLA VULGARIS, SPIRULINA PLATENSIS AND SCENEDESMUS QUADRICAUDA
}

\author{
${ }^{1}$ Jalal K.C.A., ${ }^{2}$ Md. Zahangir Alam, ${ }^{1}$ Matin W.A., ${ }^{1}$ KamaruZzaman B.Y., \\ ${ }^{1}$ AKBAR J. AND ${ }^{3}$ TOFFAZEL HOSSAIN \\ ${ }^{1}$ Department of Biotechnology, Kulliyyah of Science, \\ International Islamic University Malaysia, Jalan Sultan Ahmad Shah, \\ Bandar Indera Mahkota, 25200, Kuantan Pahang, Malaysia. \\ ${ }^{2}$ Department of Biotechnology Engineering, Kulliyyah of Engineering, \\ International Islamic University Malaysia, Jalan Gombak, \\ 53100, Kuala Lumpur, Malaysia. \\ ${ }^{3}$ Ministry of Health and Family Welfare Bangladesh. \\ jkchowdhury@iium.edu.my
}

\begin{abstract}
Nitrate and phosphorus in wastewater contribute to health and environmental threats as they are linked to illnesses as well as ecosystem disruption via algal blooms in contaminated water bodies. Based on above perspectives a comparative study was conducted on three local freshwater microalgae:Chlorella vulgaris, Spirulina platensis and Scenedesmus quadricauda to evaluate their effects on nitrate and phosphorus removal from municipal wastewater sludge (MWS). Algae performance in removing nitrate and phosphorus was evaluated by measuring nitrate and phosphorus content of MWS incubated with the strains for 7 days. Instantaneous readings were taken every 48 hours to determine periodic levels of the nutrients phosphate and nitrate. $\mathrm{BOD}_{5}$ was also evaluated to identify the strain with the most robust growth that would demand for oxygen the most in the dark. Spirulina platensis was shown as the most efficient microalgae to reduce nitrate in MWS and the best-growing among the three strains, while Chlorella vulgaris removed phosphorus the most effectively. Thus Spirulina and Chlorella could be potential candidates by showing their intrinsic merit for the reduction of phosphate and nitrate in wastewater treatment.
\end{abstract}

ABSTRAK: Nitrat dan fosforus dalam air sisa menggugat kesihatan dan mengancam alam sekitar memandangkan ia berkait dengan penyakit-penyakit serta gangguan terhadap ekosistem melalui pembiakan alga dalam air yang tercemar. Berdasarkan perspektif di atas, satu kajian perbandingan telah dijalankan terhadap tiga mikro alga air tawar tempatan : Chlorella vulgaris, Spirulina platensis dan Scenedesmus quadricauda untuk dinilai kesannya terhadap penyingkiran nitrat dan fosforus dari enap cemar air sisa bandaran (municipal wastewater sludge (MWS)). Kebolehan alga dalam penyingkiran nitrat dan fosforus dikaji dengan menyukat kandungan nitrat dan fosforus dalam MWS yang dieramkan dengan strain ini selama 7 hari. Bacaan serta-merta diambil setiap 48 jam untuk menentukan tahap berkala nutrien fosfat dan nitrat. $\mathrm{BOD}_{5}$ juga dinilai untuk mengenal pasti strain yang membesar dengan cepat yang memerlukan bekalan oksigen paling banyak dalam gelap. Spirulina platensis dikenal pasti sebagai mikro alga yang paling cekap dalam pengurangan nitrat dalam MWS dan paling cepat tumbesarannya, manakala Chlorella vulgaris menyingkir fosforus dengan paling berkesan. Maka Spirulina and Chlorella berpotensi dalam mengurangkan fosfat dan nitrat dalam rawatan air sisa. 


\begin{abstract}
KEYWORDS: Chlorella vulgaris; Spirulina platensis; Scenedesmus quadricauda; nitrate; phosphate; wastewater
\end{abstract}

\title{
1. INTRODUCTION
}

Generation of wastewater, alongside consumer waste, is characteristic of any human community. This liquid byproduct of human habitation is produced through the various uses of water in everyday life, discharging with it bodily waste, cleaning agents, disposed liquids, and discarded items among other things. In the environment, when these nutrients enter water bodies in high content, eutrophication ensues as photosynthetic algae thrive to explosive proportions, killing aquatic life through either oxygen and sunlight depletion, or massive contamination of the water with deadly phycotoxins. The presence of nitrate in drinking water also raises health concerns [1] particularly for its link to the blood disorder methemoglobinemia among bottle-fed infants (blue baby syndrome), as well as increased risk of specific cancers and adverse reproductive outcomes [2]. As such, nitrate and phosphorus in wastewater have been recognized as priority targets for removal, with maximum contaminant levels (MCL) set in place to regulate water quality. The U.S. Environmental Protection Agency (EPA) MCL of $10 \mathrm{mg} / \mathrm{L}$ nitrate-nitrogen (nitrate-N) (equivalent to $45 \mathrm{mg} / \mathrm{L}$ as nitrate), and the World Health Organization (WHO) guideline of $11 \mathrm{mg} / \mathrm{L}$ nitrate- $\mathrm{N}$ (equivalent to $50 \mathrm{mg} / \mathrm{L}$ as nitrate) in particular were prescribed for protection against infant methemoglobinemia.

Biological treatment of nitrate and phosphorus in wastewater have been widely studied, with various organisms namely bacteria, fungi, protozoa and microalgae identified as potent agents for their uptake. Microalgae for one are interesting for study and application in this area for the attractive idea of 'beneficial eutrophication' at the treatment plant, which should ideally deplete the nutrients enough so that effluents discharged, would be cleaner and safer for the environment. Additionally, microalgal use in wastewater treatment has also piqued researchers' interest for the potential of using wastewater treatment plants to generate valuable, nutritious biomass for agricultural and aquacultural purposes. To date, lack of studies have been conducted on how local microalgal strains varies in efficiency of nutrient uptake from wastewater. The interest of this study is thus to compare the performance of these three Malaysian freshwater microalgae in removing nitrate and phosphorus from local municipal wastewater.

\section{A) Municipal Wastewater as a Source of Nutrient Pollution}

USEPA [3] reported in its manual that the toilet use is the main source of nitrogen compared to basin, sink and appliance use (Table 1). Food waste disposal makes the second biggest source of wastewater nitrogen as per the context of the report, where food grinder use is widespread in the community. Nitrate in wastewater is generally produced as an intermediate of nitrogen metabolism by microorganisms, beginning with ammonification of proteins or other nitrogen-containing compounds, followed by nitrification of ammonia into nitrite, and later, oxidation of nitrite into nitrate. Based on the understanding nitrate accumulation becomes a concern in water quality management. Contrary to nitrate, phosphorus levels do not fluctuate as much, with this nutrient persisting from early on alongside other forms of phosphorous compounds in the wastewater production line. The significant phosphorus content in wastewater is largely blamed on detergent use, where predetergent days saw only 3 to $4 \mathrm{mg} / \mathrm{L}$ of phosphorus in treated municipal wastewater compared to the 10 to $20 \mathrm{mg} / \mathrm{L}$ concentrations reported more recently. In addition to detergents, phosphorous compounds are also used for corrosion control in water supply as well as industrial cooling systems. 
Table 1: Typical pollutants of concern in effluent from onsite wastewater treatment systems (adapted from 'On site wastewater Treatment Systems Manual, 2002').

\begin{tabular}{|l|l|}
\hline Pollutant & \multicolumn{1}{|c|}{ Public health or water resource impacts } \\
\hline Pathogens & $\begin{array}{l}\text { Parasites, bacteria, and viruses can cause communicable diseases through } \\
\text { direct or indirect body contact or ingestion of contaminated water or shellfish. } \\
\text { Pathogens can be transported for significant distances in ground water or } \\
\text { surface waters. }\end{array}$ \\
\hline Nitrogen & $\begin{array}{l}\text { Nitrogen is an aquatic plant nutrient that can contribute to eutrophication and } \\
\text { dissolved oxygen loss in surface waters, especially in nitrogen-limited lakes, } \\
\text { estuaries, and coastal embayments. Algae and aquatic weeds can contribute } \\
\text { trihalomethane (THM) precursors to the water column that might generate } \\
\text { carcinogenic THMs in chlorinated drinking water. Excessive nitrate-nitrogen in } \\
\text { drinking water can cause methemoglobinemia in infants and pregnancy } \\
\text { complications. }\end{array}$ \\
\hline Phosphorus & $\begin{array}{l}\text { Phosphorus is an aquatic plant nutrient that can contribute to eutrophication } \\
\text { of phosphorus-limited inland surface waters. High algal and aquatic plant } \\
\text { production during eutrophication is often accompanied by increases in } \\
\text { populations of decomposer bacteria and reduced dissolved oxygen levels for } \\
\text { fish and other organisms. }\end{array}$ \\
\hline
\end{tabular}

\section{B) Biological Approaches to Nitrate and Phosphate Removal}

Various means of reducing the nutrient load of wastewater have been introduced and implemented, whether physicochemical or biological. Alongside techniques like ion exchange, gas stripping, and breakpoint chlorination for nitrogen as well as coagulation/sedimentation by metal salt or lime for phosphorus [4], employment of biological agents proves to be an intriguing and attractive approach for researchers and investors alike. The attractiveness of this approach lies in its seemingly simple principle of letting natural, living agents capable of functioning and reproducing independently process the pollutants out of the wastewater. Removal by bacteria is currently the best-explored, with most systems incorporating the approach relying on the role of resident bacteria in the nitrogen cycle to achieve their goals. Not much difference is seen with biological phosphorus removal, as seen in most contributions to the literature which targeted and discussed both nutrients mutually. There was considerable success thus far, with significant reductions in nutrient levels of wastewater documented and reported in numerous cases, promising better prospects for water quality management.

\section{C) Algae as an Agent of Waste Removal}

Alage are photosynthetic, pigment-producing, protein-rich microorganisms especially play vital role for treating wastewater treatment systems for their unique ability to generate their own carbon source and oxygen, greater visibility that aids growth monitoring, and high commercial value. These traits excellently complement their notable capacity in nitrogen and phosphorus uptake for synthesis of cellular proteins and other essential biomolecules. Microalgae such as Chlorella sp. and Scenedesmus sp. are commonly sighted at treatment tanks, especially in warmer climates, naturally colonizing wastewater postsecondary treatment at high rate and possessing high nutrient removal capabilities [4]. In Hong Kong, Tam and Wong (1994) [5] investigated the feasibility of cultivating 
Chlorella pyrenoidosa in primary settled sewage for inorganic nutrient removal, and up to $80 \%$ of nitrogen was removed from the settled sewage, whereas phosphorus content was reduced to 1-2 $\mathrm{mg} / \mathrm{L}$ following a week of culture. By cultivating the microalgae in suspension, the research setup allowed for greater mobility of these nutrient-removing agents within the substrate. A study on pitted four polar strains of mat-forming cyanobacteria-Phormidium subfuscum, P. tenue, unidentified Oscillatoria, and Schizothrix calcicola-against a tropical strain, Phormidium bohneri to assess their nutrient uptake in temperatures as low as $50^{\circ} \mathrm{C}$ [6]. This high-latitude study also raised a significant point in its design: in order for biomass harvesting post-treatment to be more efficient, it is more preferable to employ species with a natural tendency to aggregate, such as epilithic or benthic filamentous cyanobacteria. Based on above perspectives, this study was aimed to evaluate nitrate and phosphate reduction in MWS used as a growth medium for the microalgal strains such as Chlorella vulgaris and Scenedesmus quadricauda - both genera commonly found colonizing wastewater-as well as Spirulina platensis, a matforming filamentous alga.

\section{MATERIALS AND METHODS}

\subsection{Sludge Collection}

Sludge used as substrate for this research was collected from the Indah Water Konsortium (IWK) wastewater treatment plant in Titiwangsa, Kuala Lumpur. The sludge obtained from the gravity thickener at the facility was filtered on-site with a mesh and transferred into a polymer container for storage.

\subsection{Substrate Preparation}

Sludge was stored in a polymer container following collection and stored at $4^{\circ} \mathrm{C}$. For use as substrate, the collected sludge was diluted with distilled water to $20 \%$ the original concentration and transferred to $250 \mathrm{ml}$ conical flasks (minireactors) for incubation. The substrate-containing minireactors (Fig. 3.3) were then autoclaved at $121^{\circ} \mathrm{C}$.

\subsection{Algal Strains Culture}

Chlorella vulgaris, Spirulina platensis and Scenedesmus quadricauda were purchased from University of Malaya Algae Culture Collection (UMACC) for this research. $C$. vulgaris and $S$. quadricauda were suspended in Bold's Basal Medium (BBM) while $S$. platensis was grown in Kosaric medium [7]. The purchased cultures were then maintained in an incubator-shaker at $150 \mathrm{rpm}$ and $37^{\circ} \mathrm{C}$.

\subsection{Incubation}

Ten milliliters from each strain was aseptically transferred into the sterilized minireactors in triplicates. The inoculated minireactors were then labeled as CV1, CV2, CV3 (C. vulgaris); SP1, SP2, SP3 (S. platensis); and SQ1, SQ2, SQ3 (S. quadricauda) while sterile sludge was used as control. The mini reactors were incubated in the incubator shaker at $150 \mathrm{rpm}$ and $37^{\circ} \mathrm{C}$ with an electric bulb as the light source for one week.

\subsection{Data Collection and Analysis}

HACH DR/2400 spectrophotometer was used for nitrate and phosphorus content analysis [8], [9]. Nitrate detection $\left(\mathrm{mg} / \mathrm{L} \mathrm{NO}_{3}-\mathrm{N}\right)$ was done using the chromotropic acid method, and for reactive phosphorus (orthophosphate) detection $\left(\mathrm{mg} / \mathrm{L} \mathrm{PO}_{4}{ }^{3-}\right)$, the PhosVer TM 3 method. Absorbance for both tests was $410 \mathrm{~nm}$ and $880 \mathrm{~nm}$ respectively. A sample from each mini reactor was collected every 48 hours, and nitrate and phosphorus 
reading was taken using $\mathrm{HACH}$ DR/2400 via steps outlined in the User Manual. For both tests, reading was done three times on each sample for accuracy.

\section{6 $\mathrm{BOD}_{5}$}

Four $250 \mathrm{ml}$ samples of wastewater sludge-one sterile and the others inoculated with an algal species each-were prepared for biochemical oxygen demand (BOD) analysis following incubation. All samples were saturated with oxygen using an air pump, and the initial dissolved oxygen (DO) level was taken using YSI 5000 DO meter for each sample. After 5 days of incubation in the dark, the final DO level was taken, and the difference between final and initial levels were recorded.

\section{RESULTS AND DISCUSSION}

\subsection{Nitrate and Phosphate Removal by Microalgae}

After a week of incubation in MWS (pH 6, 37 ${ }^{\circ} \mathrm{C}, 150 \mathrm{rpm}$ and $60 \mathrm{~W}$ light) and four periodic readings, changes were observed in the nitrate and phosphate content of the mini reactors. Both nutrients displayed a general decrease in level within mini reactors inoculated with the three local strains (Fig. 1 and Fig. 2). CV, SP, SQ and C refer to Chlorella vulgaris, Spirulina platensis, Scenedesmus quadricauda, and Control respectively. Both Phosphate and Nitrate were reduced by 40 to 50 percent, assessed from the margin of change from the initial nitrate concentration to the lowest achieved concentration in any one of these mini reactors. Spirulina platensis exhibited the largest reduction in nitrate content, followed by Chlorella vulgaris, then Scenedesmus quadricauda. SP mini reactors also displayed a steadier decrease in nitrate content, compared to $\mathrm{CV}$ and SQ which exhibited fluctuations at different points in time. Reduction in phosphate content was between 30-40\% approximately, based on the margin of change from the initial concentration to the lowest achieved concentration in any of the three groups. CV minireactors displayed the largest reduction in phosphate, followed by the SQ group, then SP.

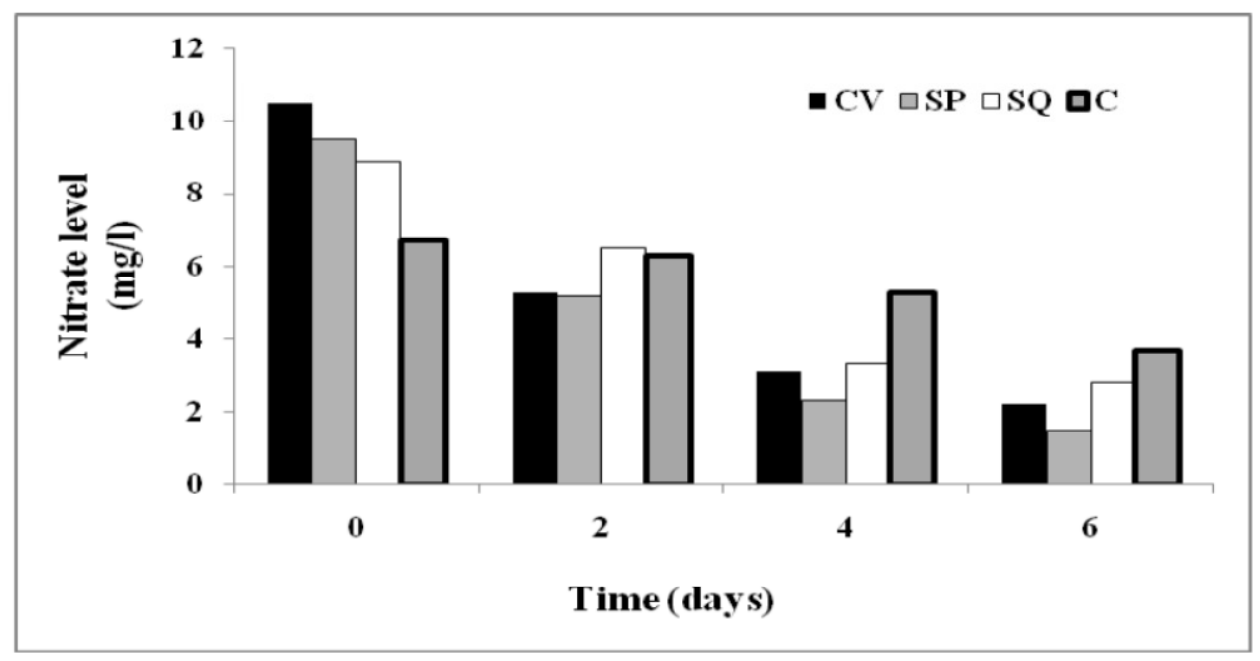

Fig. 1: Nitarte level in presence of different microalgae. 


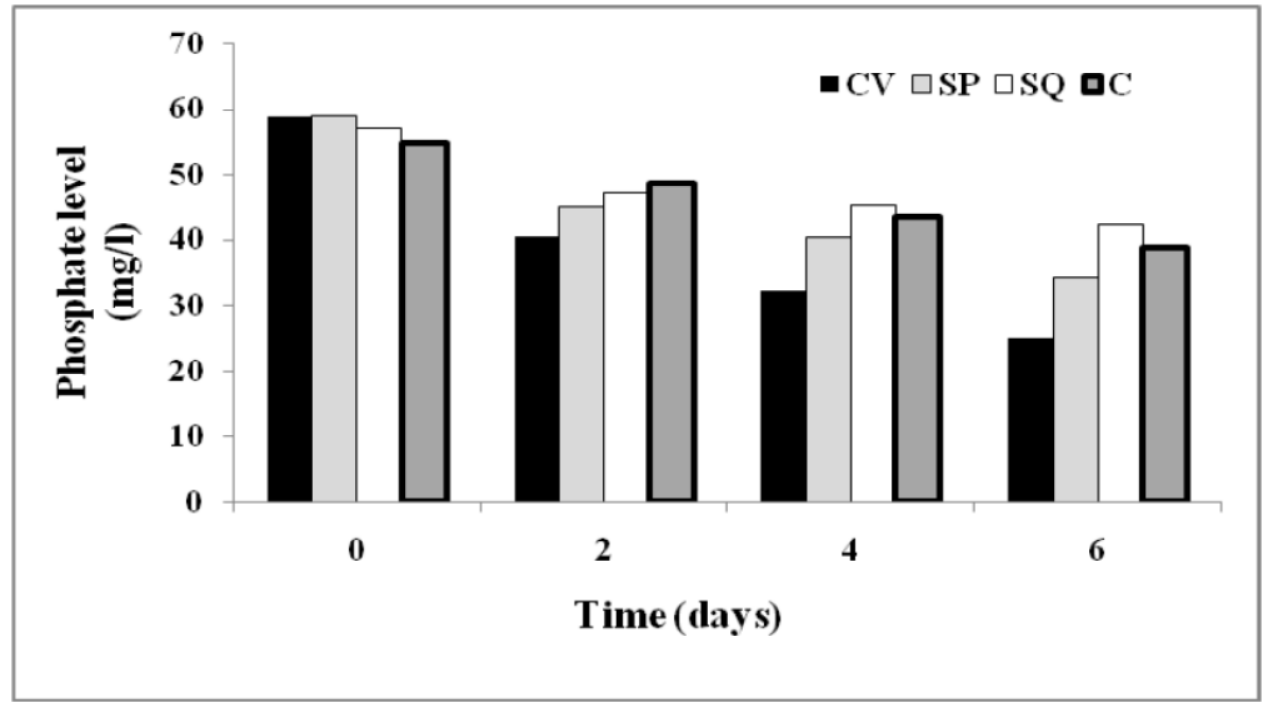

Fig. 2: Phosphate level in presence of different microalgae.

The nutrient-removing capability of microalgae-as explored and documented in various studies previously-was demonstrated yet again in the setup for this study. Significant removal of nitrate and phosphorus from WMS took place within the algal mini reactors, evidence of the biological activity of the three strains. The living cells drew much-needed nitrate and phosphorus from their wastewater environment for synthesis of amino acids, pigments, nucleic acids, ATP, biochemical precursors etc. Absence or limitation of these nutrients would otherwise lead to retardation in growth, metabolic efficiency, and ultimately survival in the environment. Phycocyanin, an essential pigment in algal photosynthesis, has been reported to degrade more rapidly in nitrogen-limited cells and supplying cells with nitrogenous compounds would restore this pigment to healthy levels [10]. Spirulina platensis was the leading species in phosphate and nitrate removal, as observed in the SP mini reactors' steadier and steeper decline in nitrate content.

Table 2: Removal of nitrate level in wastewater by using microalgae.

\begin{tabular}{|c|c|c|c|c|}
\hline Days & CV & SP & SQ & C \\
\hline $\mathbf{0}$ & 10.5 & 9.5 & 8.9 & 6.7 \\
\hline $\mathbf{2}$ & 5.3 & 5.2 & 6.5 & 5.3 \\
\hline $\mathbf{4}$ & 3.1 & 2.3 & 3.3 & 3.3 \\
\hline $\mathbf{6}$ & 2.2 & 1.5 & 2.8 & 2.8 \\
\hline
\end{tabular}

Nitrate level reduced less in and compared to microalgae strains. As the control MWS was kept sterile throughout incubation, this observation could be attributed to chemical oxidation of nitrogenous compounds like nitrite into nitrate [11]. Algal cells in SP displayed greater efficiency in removing nitrate whether originally present or generated from chemical breakdown in the substrate throughout the study periods. This enhanced ability to remove nitrate is likely attributable to the tendency in Spirulina platensis to aggregate and form mats. The intricate filamentous network of living cells with shared nitrate removal efficacy might have been advantageous for Spirulina platensis over a more 
unicellular distribution such as in Chlorella vulgaris and Scenedesmus quadricauda. In removing phosphorus on the other hand, Chlorella vulgaris appeared more adept than its counterparts while Spirulina platensis was slowest throughout the study periods (Table 3).

Table 3: Removal of Phosphate level in waste water by using microalgae.

\begin{tabular}{|c|c|c|c|c|}
\hline Days & CV & SP & SQ & C \\
\hline $\mathbf{0}$ & 58.80 & 58.98 & 57.00 & 54.78 \\
\hline $\mathbf{2}$ & 40.47 & 45.19 & 47.10 & 48.55 \\
\hline $\mathbf{4}$ & 32.20 & 40.32 & 45.27 & 43.55 \\
\hline $\mathbf{6}$ & 24.84 & 34.32 & 42.39 & 38.79 \\
\hline
\end{tabular}

Pre-culture conditions have been studied previously [12] and found to be a factor affecting phosphorus uptake in a cyanobacterial species, Microcystis aeruginosa. M. aeruginosa pre-cultured in phosphorus-poor medium (starved) was observed to have a higher phosphorus uptake rate than those pre-cultured in well supplemented medium. A similar effect might have taken place with the cultured Spirulina platensis, also a cyanobacterium, originating from a phosphorus-enriched medium (Kosaric). The setback in Spirulina platensis' phosphorus removal in comparison with its counterparts was potentially attributable to its phosphorus-rich medium of origin, which might have reduced its phosphorus-uptake capacity [13].

\section{2 $\mathrm{BOD}_{5}$}

Microalgae used were all photoautotrophic which did not require for organic carbon sources; hence oxygen demand calculated would correlate more with algal respiration [14] where the greater the oxygen uptake, the more likely for the strain to have grown substantially in the medium. $S$. platensis container was observed to have the highest $\mathrm{BOD}_{5}$ among the three strains, followed by Chlorella vulgaris and Scenedesmus quadricauda. Spirulina platensis was thus roughly evaluated as the best-growing in the MWS medium compared to the other two. This is particularly interesting as Spirulina platensis is not known to be as common in waste water environments as Chlorella spp. and Scenedesmus spp. Another interesting study observed that Spirulina platensis requires alkaline (pH 9) environments [14] yet the $\mathrm{pH}$ of the MWS used as substrate ranged from 5.9 to 6.2. This slightly acidic $\mathrm{pH}$ of the MWS did not seem to affect its growth as much, as seen from the better performance shown in nitrate removal and greater oxygen demand in respiration.

\section{CONCLUSION}

As the observations showed that Spirulina platensis showed better efficiency than those of others in nitrate removal and overall growth, while Chlorella vulgaris dominated in phosphorus removal. Spirulina platensis' exceptional performance in nitrate uptake was most likely contributed by the shared function of the aggregated cells and more robust growth. A delicate interaction of roles between cell die-offs and nitrate generation through chemical oxidation was suggested as the cause behind the slower nitrate removal by Chlorella vulgaris and Scenedesmus quadricauda. These findings have certainly shed light on the differences in value of employing different algal species in wastewater treatment. Spirulina platensis and Chlorella vulgaris have certainly proven to be leading species in 
basic nutrient treatment of wastewater, and the health, environmental and commercial benefits cannot simply be ignored. Furthermore these microalgae could be instrumental for the conversion of 'Waste to Wealth' in our environment.

\section{REFERENCES}

[1] M. J. Hill,. "Nitrates and nitrites in food and water". Woodhead Publishing.Jennett, J. C., Hassett, J. M. \& Smith, J. E. (1980). The Use of Algae to Control Heavy Metals in the Environment. Environmental Geochemistry and Health. Vol.2 (1):26-31, 1991.

[2] M. H. Ward, T. M. deKok, P. Levallois, J. Brender, G. Gulis, B. T. Nolan, and J. VanDerslice,. "Workgroup Report: Drinking-Water Nitrate and Health-Recent Findings and Research Needs". Environmental Health Perspectives. Vol. 113 (11): 1607-14. 2005.

[3] US EPA,. "Onsite wastewater treatment systems manual". 2002. Office of Water, Office of Research and Development: U.S. Environmental Protection Agency.

[4] P. Chevalier, D. Proulx, P. Lessard, W. F. Vincent, and J. de la Noue,. "Nitrogen and phosphorus removal by high latitude mat-forming cyanobacteria for potential use in tertiary wastewater treatment". Journal of Applied Phycology. Vol.12: 105-112, 2000.

[5] N. F. Y., Tam., and Wong, Y.S. "Feasibility of Using Chlorella pyrenoidosa in the Removal of Inorganic Nutrients from Primary Settled Sewage". In S.M. Phang, Y.K. Lee, M.A. Borowitzka \& B.A. Whitton (Eds.) Algal Biotechnology in Asia-Pacific Region (pp. 29199). 1994. University of Malaya: Kuala Lumpur.

[6] Phang, S. M. and Chu, W. L. Catalogue of strains. University of Malaya Algae Culture Collection: Kuala Lumpur. 1999.

[7] A. D., Eaton, L. S. Clesceri, E. W. Rice, and A. E. Greenberg, and M. H. Franson,. "Standard methods for the examination of water \& wastewater"., 2005. Centennial Edition. APHA/AWWA/WEF.

[8] L. E. Bashan, J. P. Hernandez, and Y. Bashan,. "Microalgae growth-promoting bacteria as "helpers" for microalgae: a novel approach for removing ammonium and phosphorus from municipal wastewater. first international meeting on microbial phosphate solubilization. 2003.

[9] HACH,. “DR/2400 Spectrophotometer Procedure Manual”. 2004. Hach Company:USA.

[10] L. Lishman., "The influence of substrate and temperature on biological nitrogen removal in wastewater treatment systems". 1997. University of Waterloo: Canada.

[11] I. M. Rafiqul, K.C.A. Jalal and M.Z. Alam., Environmental factors for optimization of Spirulina biomass in laboratory culture. Biotechnology. Vol. 4 (1): 19-22. 2005.

[12] M. Okada, R. Sudo, and S. Aiba., "Phosphorus uptake and growth of blue-green alga, Microcystis aeruginosa. Biotechnology \& Bioengineering. Vol.24 (1): 143-52. 2004.

[13] M. A. Aziz and W. J. Ng,. "Optimizing Algal Growth in Treating Wastewater Effluents by Activated Algae-Reactor". In S.M. Phang, Y.K. Lee, M.A. Borowitzka \& B.A. Whitton (Eds.) Algal Biotechnology in Asia-Pacific Region. pp. 285-90. 1994. University of Malaya: Kuala Lumpur.

[14] I. S. M. Rafiqul,. "Growth and biochemical composition of Spirulina platensis \& S. fusiformis under different culture conditions". 2004. PhD Thesis. Kolej Universiti Sains \& Teknologi Malaysia. 